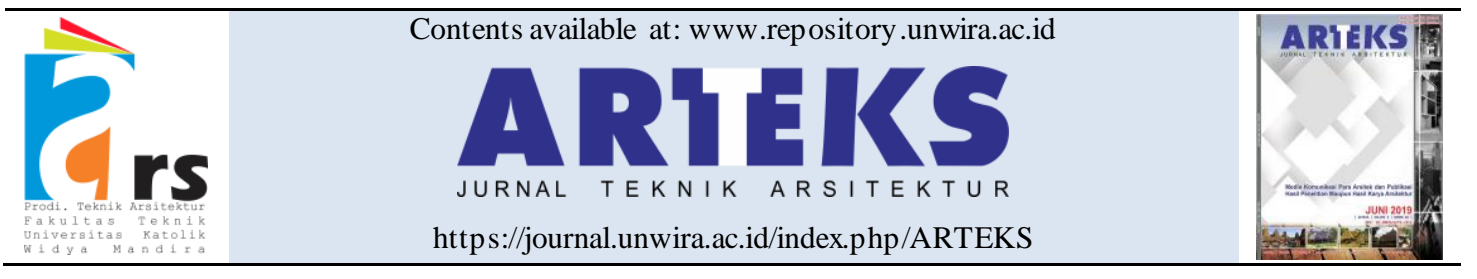

Editorial paper

doi: 10.30822/arteks.v6i1.1009

\title{
Investigating locality: Socio-cultural and technological perspectives
}

\author{
Yandi Andri Yatmo* (D), Paramita Atmodiwirjo (i) \\ Universitas Indonesia \\ *Email: yandiay@gmail.com

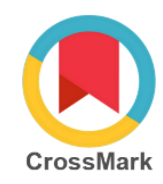

This edition of ARTEKS: Jurnal Teknik Arsitektur presents a series of the investigation into the locality as an attempt to contribute to the development of architectural knowledge that addresses particular contexts. In architecture, as in many otherdisciplines, knowledge is developed and transformed through inquiry and investigation, as a means to take a position in relation to the existing knowledge. Knowledge is established through the process of dialectic that contains three parts: the thes is as the originating idea, position, or statement; the antithes is as the opposite or counter-argument to the thesis; and the synthesis as the reconciliation or transformation of those two (Fichte 1868). Through the continuing process of dialectic, knowledge is not static and limited to what has been known before but is continuously transformed through questioning, arguing, and re-positioning. Research as a form of inquiry and investigation plays an important role in establishing the debate within the discipline (Smith and Guitart 2012) to push the boundaries of knowledge. Architecture as a form of knowledge should be developed through research (Till 2011), which could be performed through a range of research methods (Groat and Wang 2013; Lucas 2016).

One of the roles of research in architecture is to discover new knowledge regarding humans and their built environment. In establishing new knowledge, it is important in architectural research to question the existing knowledge and to raise the questions never asked before. Some of the questions need to be asked because there have not been any adequate explanations regarding the phenomena that are specific to particular contexts. Investigation of locality becomes an opportunity to establish new knowledge pertaining to specific socio-cultural contexts. Investigation of locality has a critical value as an attempt to discover the way the society operates in a particular way (Certeau 1980). Such understanding could not depend on the dominant literature and discourses of Western architecture that has dominated our practice and education of architecture for some time. Many aspects of locality could not be explained simply by the generic methods of building such as prescribed by Durand (2000) and Vitruvius (1960) or by the rational thinking prescribed by Le Corbusier (1985) and otherkey figures of modern architecture. It is necessary to promote the investigation of local aspects of architecture to enable the architectural knowledge and practice to be more relevant and contextual.

Investigation of locality becomes important as an attempt to navigate between the local values and global culture that have manifested through the design and materiality of the built environment (Atmodiwirjo and Yatmo 2020). Various forms of architecture and building practice that are specific to particular contexts offer important contributions in establishing architectural knowledge that is neces sary for the resilience of local architecture within the global, modern culture. The understanding of the peculiarity of particular places has become a strategy to maintain local value within the challenge of modernity (Frampton 1983). Investigation from the perspectives of socio-cultural and technological perspectives becomes important to establish a comprehensive knowledge of various aspects of locality in architecture.

At the same time, the inquiry into the locality is also a challenge since very often we are already "immersed" into what seems to be very close to us (Wigglesworth and Till 1998). Many of the local aspects of architecture are related to the everyday life of the society that is mundane and ordinary 
(Certeau 1980). It requires appropriate strategies to reveal the layers of knowledge on locality and the everydayness of the society that is embedded within the materiality of the built environment, which is often present as qualities that are not always tangible (Ingold 2007). It is necessary to establish research agenda to investigate the locality by maintaining the research quality through originality, significance, and rigor (Till 2011). Appropriate methods of inquiry need to be established in order to maintain the architectural scholarship on the knowledge of the locality.

This issue of ARTEKS: Jurnal Teknik Arsitektur contains fifteen articles that present various attempts to investigate some aspects of locality from socio-cultural and technological perspectives. Some articles address the socio-cultural aspects of locality through the investigation of the actions and relationships among actors (Prasetyo \& Ekomadyo) and the sense of place perceived by the society (Lesmana et al.). Others investigate the cultural meaning of in-between space (Manurung \& Pramitas ari), the cultural meaning of roof as a spatial element (Mintareja et al.), and the inquiry into the cosmological concepts as the basis of the spatial organization (Lestari et al.). These studies demonstrate how the presence and materiality of the built environment in a particular locality could not be separated from the socio-cultural aspects of the society inhabiting it. The other three articles address the importance to understand the social-psychological needs and experience of the local users as the inhabitants of the built environment. These are the studies on the personalization of dwelling (Morakinyo), the provision of seating facilities for the elderly (Pramitasari et al.), and the transformation of living space in governmentsubsidized housing (Simbolon et al.). They suggest the importance to obtain knowledge from the perspective of the users in order to create a better quality of the living environment.

Some other articles take on the technological perspectives as a means to reveal the possible techniques, methods, and strategies derived from the specific contexts. Some studies conducted investigations on the effect of additional ingredients in local brick material production (Bebhe \& Daton), the reuse of materials to cater to regional housing needs (Wibowo \& Dwisusanto), and the design strategies to address the contextuality of form to its local surrounding (Gandawijaya) Other studies employ prototyping and ethno-modeling as alternative methods of inquiry to explore the specific local architectural elements and construction (Hariyadi et al., Yusran et al.), satellite imagery for the detection of potential green open space (Wikantiyoso et al.), and scenic beauty estimation for visual landscape evaluation (Dharmadiatmika \& Krisnandika). These studies suggest the potential for developing innovative techniques and methods to understand the potential of architectural materiality and environmental contexts as a means to develop more contextual architectural design practice.

Investigation of locality offers a wide range of possibilities to maneuver within the richness of sociocultural and environmental conditions through research as well as design practice. It becomes important to continue asking questions on locality as well as defining appropriate inquiry methods to gain valuable knowledge on the locality that could contribute to the current knowledge of architecture.

\section{Referensi}

Atmodiwirjo, Paramita, and Yandi Andri Yatmo. 2020. “Tanahku Indonesia” : On Materialscape as the Materiality of a Nation'. Architecture and Culture 8 (2): 328-49. https://doi.org/10.1080/20507828.2020.1774850.

Certeau, Michel de. 1980. Practice of Everyday Life. California: University of California Press.

Corbusier, Le. 1985. Towards a New Architecture. Mineola, New York: Dover Publications.

Durand, Louis. 2000. Précis of the Lectures on Architecture. Edited by David Britt and Antoine Picon. Los Angeles, California, United States: Getty Research Institute.

Fichte, Johann Gottlieb. 1868. The Science of Knowledge.Philadelphia: Lippincott \& Co.

Frampton, Kenneth. 1983. 'Towards a Critical Regionalism: Six Points for an Architecture of Resistance'. In The Anti-Aesthetic Essays on Postmodern Culture, edited by Hal Foster, 16-30. Port 
Townsend, Washington: Bay Press. https://monoskop.org/images/0/07/Foster_Hal_ed_The_AntiAesthetic_Essays_on_Postmodern_Culture.pdf.

Groat, Linda N., and David Wang. 2013. Architectural Research Methods. 2nd ed. New York: John Wiley \& Sons, Inc.

Ingold, Tim. 2007. 'Materials against Materiality'. Archaeological Dialogues 14 (1): 1-16. https://doi.org/10.1017/S1380203807002127.

Lucas, Raymond. 2016. Research Methods for Architecture. London, England: Laurence King Publishing.

Smith, Korydon, and Miguel Guitart, eds. 2012. Introducing Architectural Theory: Debating a Discipline. 1sted. United Kingdom: Routledge.

Till, Jeremy. 2011. 'Is Doing Architecture Doing Research?' In 4IAU $4^{a}$ Jornadas Internacionales Sobre Investigación En Arquitectura y Urbanismo. Valencia: Universitat Politècnica de València.

Vitruvius. 1960. The Ten Books on Architecture. Mineola, New York: Dover Publications.

Wigglesworth, Sarah, and Jeremy Till, eds. 1998. The Everyday and Architecture (Architectural Design). Academy Press. 
ARTEKS : Jurnal Teknik Arsitektur, Volume 6 Issue 1, April 2021

pSSN 2541-0598; eISSN 2541-1217 